\title{
Pengaruh Gaya Kepemimpinan Transformasional terhadap Komitmen Organisasional dengan Kepuasan Kerja sebagai Variabel Intervening Pegawai Fakultas $X$ di Perguruan Tinggi $Y$
}

\author{
Donny Setyawan', Dwi Ratmawati ${ }^{2}$ \\ ${ }^{1}$ Program Magister Sains Manajemen, Universitas Airlangga, Kampus B Jln Airlangga 4-6 Surabaya, 60286
}

Correspondence: Donny Setyawan (dontyei@gmail.com)

Received: 080821 - Revised: 150821 - Accepted: 160821 - Published: 280921

\begin{abstract}
Abstrak. Pandemi yang melanda di berbagai belahan dunia pada saat ini mempengaruhi pola kerja setiap individu dan organisasi, saat pandemi, tantangan organisasi Pendidikan Tinggi adalah untuk bertahan atau meraih sukses dengan memenuhi semua indikator keberhasilan kinerjanya. Salah satu faktor yang mempengaruhi keberhasilan kinerja organisasi perguruan tinggi adalah komitmen organisasional yang dipengaruhi gaya kepemimpinan, Kepemimpinan pada organisasi pendidikan tinggi pada umumnya menerapkan kepemimpinan demokratif/transformasional sedangkan komitmen organisasional memberikan pengaruh terhadap perilaku kerja seperti kinerja, kepuasan kerja, absensi pegawai dan juga turn over pegawai. Obyek penelitian pada fakultas X di Institusi Pendidikan Tinggi Y di Jawa Timur yang mengalami penurunan performa pada awal pandemik dan harus memperbaiki performa pada tahun kedua pandemi dan seterusnya memerlukan berbagai masukan dari sisi kajian manajemen sumber daya manusia, didapatkan hasil kajian Kepemimpinan Transformasional berpengaruh signifikan terhadap Kepuasan Kerja, Kepuasan Kerja memiliki pengaruh yang signifikan terhadap terhadap Komitmen Organisasional, dan Kepemimpinan Transformasional memiliki pengaruh signifikan terhadap Komitmen Organisasional melalui Kepuasan Kerja sebagai variabel intervening dengan menggunakan analisis metode PLS.
\end{abstract}

Kata kunci: Kepemimpinan Tranformasional, Kepuasan Kerja, Komitmen Organisasional, Intervening

Citation Format: Setyawan, D. Ratmawati, D. (2020). Pengaruh Gaya Kepemimpinan Transformasional terhadap Komitmen Organisasional dengan Kepuasan Kerja sebagai Variabel Intervening Pegawai Fakultas X di Perguruan Tinggi Y . Prosiding Seminar Nasional Abdimas Ma Chung (SENAM), 2020, 134-146. 


\section{PENDAHULUAN}

Sumber daya manusia dengan pengetahuan dan kompetensi merupakan aset utama dalam membantu organisasi untuk mempertahankan keunggulan kompetitif mereka (Imtiaz Ahmed et al, 2013). Kepemimpinan memainkan peran penting dalam menentukan komitmen anggota organisasi. Para peneliti menemukan bahwa pegawai yang senang dengan supervisor/pemimpin dan merasa diperlakukan dengan hormat dan dihargai oleh pemimpin, maka mereka merasa lebih terikat dengan organisasi (Stup, 2006). Salah satu faktor yang mempengaruhi komitmen organisasional yaitu dari gaya kepemimpinan, kepemimpinan adalah hubungan mempengaruhi antara pemimpin dan pengikutnya yang bertujuan untuk mencapai perubahan nyata dan memperoleh hasil yang sesuai dengan tujuan bersama (Daft, 2011). Selain itu, kepemimpinan adalah kemampuan individu untuk mempengaruhi, memotivasi dan membuat orang lain mampu memberikan kontribusinya demi efektivitas dan keberhasilan organisasi (Yukl, 2010).

Kepemimpinan pada organisasi pendidikan seperti di universitas pada umumnya menerapkan kepemimpinan demokratif dimana pemimpin melibatkan penetapan keputusan yang memungkinkan orang lain atas beberapa pengaruh pada keputusankeputusan pemimpin. Dalam kepemimpinan demokratis, bawahan ikut serta dalam penetapan sasaran dan pemecahan masalah. Pemimpin yang demokratis atau partisipatif mendesentralisasikan otoritas kepada pegawai. Keputusan dibuat tidak secara sepihak tetapi partisipatif. Putusan-putusan itu adalah hasil dari konsultasi pemimpin dengan para bawahan (Badeni, 2013). Ciri-ciri gaya kepemimpinan demokratis sebagai berikut:

a. Pendelegasian wewenang terdesentralisasi

b. Keputusan yang diambil pemimpin melibatkan opini dari bawahan

c. Komunikasi pemimpin dan bawahan dua arah

d. Berorientasi pada hubungan

e. Asumsi pada pegawai pegawai dapat bekerja sama dan bermoral

f. Perencanaan tujuan dilakukan oleh keterlibatan pegawai

Sehubungan dengan kepemimpinan dalam organisasi, tolak ukur keberhasilan kepemimpinan adalah kinerja yang baik, kualitas hasil karya personil baik, maupun kuantitas penampilan individu maupun kelompok kerja, penampilan hasil karya tidak terbatas kepada personil yang memangku jabatan fungsional maupun struktural tetapi juga kepada keseluruhan jajaran personil di dalam organisasi ( Ilyas, 2005:55). Selain itu, 
menurut konsep kinerja merujuk kepada tingkat keberhasilan dalam melaksanakan tugas serta kemampuan untuk mencapai tujuan yang telah ditetapkan. Kinerja dinyatakan baik dan sukses jika tujuan yang diinginkan dapat tercapai dengan baik. (Donelly, Gibson dan Ivancevich dalam Rivai, 2005:309). Pada dasarnya pegawai yang puas terhadap pekerjaanya akan cenderung memiliki kinerja yang tinggi pula. (Miller et.al.,1991) menyatakan bahwa gaya kepemimpinan mempunyai hubungan yang positif terhadap kepuasan kerja para pegawai.

Kepuasan kerja merupakan hal yang bersifat individual, kepuasan kerja sebagai efektivitas atau respon emosional terhadap berbagai aspek pekerjaan (Kreitner \& Kinicki, 2005). Oleh sebab itu, kepuasan kerja sangat dipengaruhi oleh faktor lingkungan kerja setiap individu. Semakin banyak faktor yang mendukung individu di dalam melakukan pekerjaannya, maka akan semakin besar pula kepuasan di dalam bekerja. Pegawai yang mempunyai keterlibatan tinggi dalam bekerja dan tidak mempunyai keinginan keluar dari organisasi merupakan modal dasar untuk mendorong produktifitas yang tinggi. Moncrief (1997) mengungkapkan bahwa komitmen pegawai terhadap organisasi yang tinggi akan berpengaruh terhadap kinerja pegawai. Komitmen organisasional menjadi perhatian penting dalam banyak penelitian karena memberikan dampak signifikan terhadap perilaku kerja seperti kinerja, kepuasan kerja, absensi pegawai dan juga turn over pegawai. Komitmen dalam organisasi akan membuat pekerja memberikan yang terbaik kepada organisasi tempat dia bekerja. Van Scooter (2000) menyatakan bahwa pekerja dengan komitmen yang tinggi akan lebih berorientasi pada kerja. Disebutkan pula bahwa pekerja yang memiliki komitmen organisasi tinggi akan cenderung senang membantu dan dapat bekerja sama.

Komitmen organisasional didefinisikan oleh Luthans (1995) sebagai sikap yang menunjukkan loyalitas pegawai dan merupakan proses berkelanjutan bagaimana seorang anggota organisasi mengekspresikan perhatian mereka kepada kesuksesan dan kebaikan organisasinya. Lebih lanjut sikap loyalitas ini diindikasikan dengan tiga hal, yaitu : (1) keinginan kuat seseorang untuk tetap menjadi anggota organisasinya, (2) kemauan untuk mengerahkan usahanya untuk organisasinya, (3) keyakinan dan penerimaan terhadap nilai-nilai dan tujuan organisasi. Komitmen organisasional berkaitan dengan mutu pelayanan organisasi. Pada Fakultas $\mathrm{X}$ Perguruan Tinggi $\mathrm{Y}$ terindikasi terdapat penurunan mutu pelayanan organisasi yang terjadi pada tahun 2019 ke tahun 2020 
Perguruan Tinggi Y mempunyai visi menjadi perguruan tinggi berkelas dunia yang membuat Perguruan Tinggi Y melakukan banyak perubahan, salah satu perubahan adalah sistem organisasi dan tata kelola, salah satunya perubahan struktur organisasi fakultas, dari awalnya berjumlah 4 departemen pada tata Kelola 2014-2019 dirubah menjadi 6 departemen pada tata Kelola 2019-2024, dekan fakultas memiliki target untuk mencapai indikator kinerja yang tertuang dalam kontrak kerja yang selalu diperbarui setiap tahunnya, departemen A, B, C, D, E dan F adalah departemen dibawah fakultas X, tiga diantaranya adalah departemen dengan bidang keilmuan desain, sedangkan 3 lainnya adalah departemen dengan bidang keilmuan sosial, bisnis dan manajemen teknologi. Masa transisi sebagai fakultas baru yang wajib untuk mengikuti visi organisasi Perguruan Tinggi $\mathrm{Y}$ yang besar membuat Fakultas $\mathrm{X}$ harus mengelola organisasi fakultas dan departemen dibawahnya dengan baik. Key Performance Indicator Fakultas X pada tahun 2020 hingga masa semester Januari-Juli memiliki kinerja 48,90 \% dari minimal 50\% yang ditetapkan oleh Pimpinan Institusi untuk dikategorikan berperforma baik, dan fakultas X mencapai kinerja 98,75\% akhir tahun 2020, pada tahun 2019 performa kinerja Fakultas X tercapai 52\% pada masa semester kedua tahun 2019 atau ketika fakultas baru saja berdiri, sebelum menjadi fakultas $\mathrm{X}$ fakultas lama mencapai kinerja sebesar $70 \%$ atau pada saat fakultas masih menggunakan tata Kelola periode sebelumnya dengan jumlah departemen yang berbeda dengan jumlah departemen tahun 2020, pada tahun ajaran 2020 sebagai Fakultas yang masih baru, Fakultas X mendapat input nilai mahasiswa baru yang relative tinggi jika dibandingkan dengan fakultas lain sekampus yang didapat dari data nilai SBMPTN, sudah seharusnya Fakultas $\mathrm{X}$ memiliki performa kinerja yang terjaga baik. Capaian kinerja pegawai Fakultas X dapat dilihat dari Sistem Penjaminan Mutu Internal Perguruan Tinggi di kampus tersebut.

Dari data Perguruan Tinggi Y diketahui bahwa terjadi penurunan skor total nilai kinerja dari tahun 2019 ke tahun 2020 yakni dari 259,85 menjadi 249,65. Pada masa awal pandemi melanda dimana diberlakukan lockdown pada lingkungan kampus menyebabkan terjadinya kecemasan pada semua civitas akademik, perubahan cara belajar dan bekerja menjadi kekagetan perilaku pada setiap individu di kampus, cara pengawasan kerja, koordinasi kerja, cara bekerja menjadi pembiasaan baru bagi seluruh civitas akademik, persepsi negatif, kecemasan berlebih dari kondisi disekitar tidak dapat dihindari, 
tantangan untuk beradaptasi dengan kondisi awal pandemi menjadi salah satu hipotesa kenapa terjadi penurunan performa kinerja.

Dari data Penjaminan Mutu Internal tahun 2019 dan 2020 didapatkan perbedaan jumlah nilai yang signifikan ada pada standar 2, standar 3 dan standar 8 , dimana standar 2 adalah mengenai tata kelola, standar 3 mengenai mahasiswa dan lulusan, serta standar 8 mengenai pengabdian kepada masyarakat, pada standar 2 tahun 2020 deskriptor 2.3.2 didapatkan data isian kerjasama pendidikan, penelitian dan pkm ditingkat fakultas bernilai lebih rendah dibanding tahun 2019, pada deskriptor struktur organisasi dan keefektifan penyelenggara organisasi serta deksriptor komitmen UPPS mengalami penurunan skor nilai dibanding tahun 2019, pada standar 3 perbedaan signifikan ada pada isian nilai jumlah mahasiswa asing yang mengikuti kegiatan akademik di Fakultas X serta penurunan rasion keterlibatan dosen dan mahasiswa fakultas $\mathrm{X}$ dalam kegiatan pengabdian masyarakat baik dalam skala lokal maupun nasional, walaupun terdapat 3 kegiatan pengabdian masyarakat dari Fakultas $\mathrm{X}$ tersebut yang menjadi kegiatan nasional dengan dukungan dan kolaborasi satgas nasional Covid 19, pemerintah daerah propinsi dan kegiatan SDGs skala nasional namun secara rasio masih dibawah skor fakultas lainnya dalam lingkup Perguruan Tinggi Y.

Indikasi dari peningkatan kepuasan kerja individu dan kinerja suatu unit kerja itu sendiri dapat dipengaruhi oleh gaya kepemimpinan yang efektif dalam mengelola sumber daya manusia dalam suatu unit kerja juga akan berpengaruh pada perilaku kerja, yang pada akhirnya akan mempengaruhi kinerja organisasi secara keseluruhan. Seorang pemimpin juga harus mampu menciptakan komitmen organisasional pada pegawainya dengan menanamkan visi, misi, dan tujuan dengan baik untuk membangun loyalitas dan kepercayaan dari pegawainya. Selain itu pemimpin juga dituntut untuk menciptakan suasana kerja yang baik, hubungan dengan pegawai yang baik, serta membuat sistem reward yang bagus untuk pegawainya, yang pada akhirnya bertujuan untuk mencapai kepuasan kerja yang baik untuk para pegawai. Kepuasan kerja diindikasikan menjadi pemediasi pengaruh gaya kepemimpinan transformasional terhadap komitmen organisasional.

Mengingat urgensi masalah implikasi pada kondisi pandemi maka perlu diangkat penelitian mengenai gaya kepemimpinan transformasional, kepuasan kerja, dan komitmen organisasional Pada fakultas X Perguruan Tinggi Y. Berdasarkan pada uraian 
latar belakang yang dikemukakan di atas, maka permasalahan yang akan ditelaah dalam penelitian ini adalah sebagai berikut:

1. Apakah gaya kepemimpinan transformasional berpengaruh signifikan terhadap kepuasan kerja?

2. Apakah kepuasan kerja berpengaruh signifikan terhadap komitmen organisasional?

3. Apakah gaya kepemimpinan transformasional berpengaruh signifikan terhadap komitmen organisasional melalui kepuasan kerja sebagai variabel intervening?

Berdasarkan rumusan masalah diatas, maka penelitian ini bertujuan untuk mengetahui dan membuktikan bahwa gaya kepemimpinan transformasional berpengaruh signifikan terhadap kepuasan kerja, untuk mengetahui dan membuktikan kepuasan kerja berpengaruh signifikan terhadap komitmen organisasional dan mengetahui dan membuktikan gaya kepemimpinan transformasional berpengaruh signifikan terhadap komitmen organisasional melalui kepuasan kerja sebagai variabel intervening sehingga dapat menjadi referensi dan masukan bagi pelaku organisasi pendidikan tinggi lain dalam menentukan tata kelola organisasi yang baik untuk organisasinya.

\section{METODE PELAKSANAAN}

Pada penelitian ini menggunakan pendekatan metode penelitian kuantitatif, dengan penggunaan variabel seperti deskripsi berikut :

- Variabel Bebas (X) Variabel independen dalam penelitian ini adalah gaya kepemimpinan transformasional.

- Variabel Dependen (Y) Dalam penelitian ini yang menjadi variabel terikat adalah komitmen organisasional (Y).

- Variabel Intervening/Mediasi (Z) Variabel intervening adalah variabel yang secara teoritis mempengaruhi hubungan antara variabel independen dan dependen. Variabel ini merupakan variabel penyela/antara yang terletak di antara variabel independen dan dependen, sehingga variabel independen tidak langsung mempengaruhi berubahnya atau timbulnya variabel dependen (Sugiyono, 2010).

Penelitian ini menggunakan teknik analisis PLS (Partial Least Square). Uji Validitas indikator dari variabel penelitian ini terdiri atas dua bagian, yaitu convergent 
validity dan discriminant validity. Uji reliabilitas penelitian ini menggunakan nilai Cronbach Alpha.

\section{HASIL DAN PEMBAHASAN}

Hipotesis dalam penelitian ini sesuai rumusan sebelumnya adalah

a. Kepemimpinan Transformasional (KT) berpengaruh signifikan terhadap Kepuasan Kerja (KK)

b. Kepuasan Kerja (KK) berpengaruh signifikan terhadap Komitmen Organisasional $(\mathrm{KO})$

c. Kepemimpinan Tranformasional (KT) berpengaruh signifikan terhadap Komitmen Organisasional (KO) dengan Kepuasan Kerja (KK) sebagai variabel mediasi

Dari Hipotesis diatas analisis data yang pertama yang pertama kali dilakukan adalah analisis deskriptif untuk menjelaskan demografi responden dan tabel distribusi frekuensi karakteristik responden.

Tabel 1. Distribusi frekuensi jenis kelamin responden

\begin{tabular}{ll}
\hline Jenis Kelamin & Frekuensi \\
\hline Laki-laki & 65 \\
Perempuan & 51
\end{tabular}

Tabel 1 memberikan gambaran karakteristik responden berdasarkan jenis kelamin. Responden perempuan dalam penelitian ini berjumlah 51 responden dan yang laki-laki berjumlah 65 responden. Pada tabel 2 menjelaskan proporsi usia responden didominasi usia kerja produktif pada rentang usia 32-38 tahun dan 39-45 tahun.

Tabel 2. Distribusi usia responden

\begin{tabular}{clc}
\hline No. & Usia & Jumlah (Orang) \\
\hline $\mathbf{1}$ & $18-24$ tahun & 11 \\
$\mathbf{2}$ & $25-31$ tahun & 12 \\
$\mathbf{3}$ & $32-38$ tahun & 28 \\
$\mathbf{4}$ & $39-45$ tahun & 21 \\
$\mathbf{5}$ & $46-52$ tahun & 18 \\
$\mathbf{6}$ & $53-59$ tahun & 20 \\
$\mathbf{7}$ & $60-66$ tahun & 6 \\
Total & & 116 \\
\hline
\end{tabular}


Tabel 3 menjelaskan informasi tentang jenjang Pendidikan responden, pada fakultas $\mathrm{X}$ didominasi pegawai dengan jenjang Pendidikan magister.

Tabel 3. Distribusi jenjang pendidikan pegawai.

\begin{tabular}{|c|c|c|}
\hline No. & Pendidikan Terakhir & Jumlah (Orang) \\
\hline 1 & Diploma/Sederajat & 8 \\
\hline 2 & Sarjana/Sederajat & 28 \\
\hline 3 & Magister & 65 \\
\hline 4 & Doktor & 15 \\
\hline Total & & 116 \\
\hline
\end{tabular}

Tahap analisis selanjutnya adalah membuat diagram jalur dan melakukan analisis PLS. diagram jalur yang dibangun dan disajikan pada gambar 2.

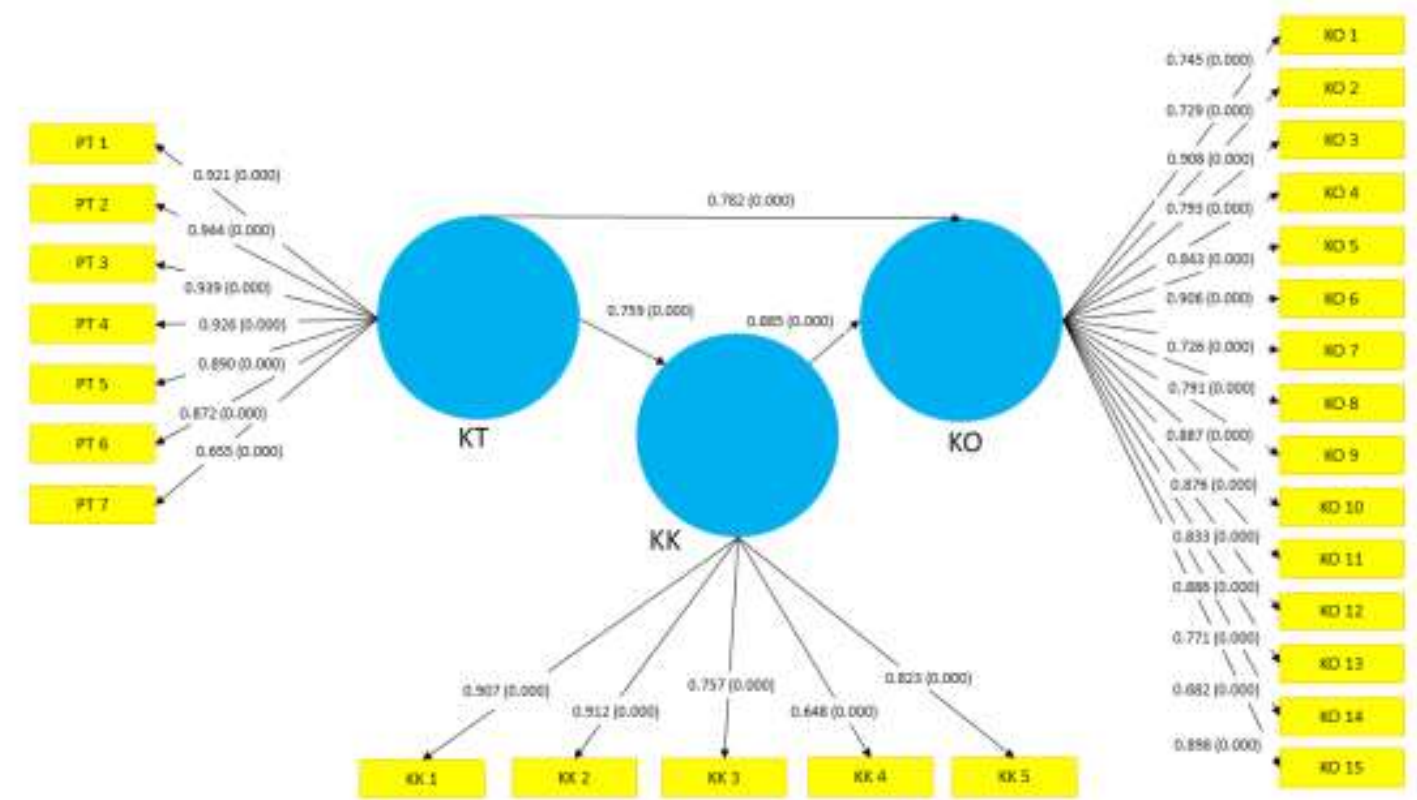

Gambar 2. Diagram jalur dengan koefisien pada inner model dan outer model

Analisis awal pada PLS sebelum pengujian hipotesis untuk memprediksi nilai hubungan antar variabel dalam model struktural, terlebih dahulu dilakukan validasi terhadap model pengukuran. Variabel dengan indikator pertanyaan dihubungkan dengan model pengukuran. Nilai outer loading antara variabel terhadap setiap indikator pertanyaan dan variabel yang dapat diuji selanjutnya dilakukan validasi. Indikator yang memiliki nilai outer loading di bawah 0,4 akan dieliminasi dari model pengukuran (Hair Jr et al., 2016). 
Variabel kepemimpinan transformasional (KT) disusun oleh 7 indikator pertanyaan dengan nilai outer loading masing-masing indikator di atas 0,6. Nilai ini memberikan informasi bahwa variabel kepemimpinan transformasional (KT) dapat menjelaskan keragaman data pada KT1, KT2, KT3, KT4, KT5, KT6, dan KT 7 dengan persentasi di atas $60 \%$. Nilai outer loading pada variabel Kepuasan Kerja (KK) dan Komitmen Organisasional (KO) di atas 0,8. Kesimpulan yang didapatkan bahwa variabel Kepuasan Kerja (KK) dan Komitmen Organisasional (KO) dapat menjelaskan keragaman data pada indikator-indikator pertanyaan penyusunnya dengan persentasi di atas $80 \%$. Evaluasi terhadap indikatorindikator pertanyaan dalam menyusun variabel juga dapat dilihat dari nilai composite reliability dan Average Variance Extracted (AVE).

Tabel 4. Nilai composite reliability, dan AVE. Nilai AVE yang dihasilkan harus lebih besar dari 0,5. Untuk nilai Composite Reliability harus diatas 0,7.

Tabel 4. Composite Reliability dan AVE

\begin{tabular}{ccc}
\hline Variabel & Composite Reliability & AVE \\
& & \\
\hline KT & 0,87 & 0,79 \\
KK & 0,91 & 0,81 \\
KK & 0,89 & 0,61 \\
\hline
\end{tabular}

Berdasarkan hasil analisis pada tabel 4, diketahui bahwa untuk nilai Composite Reliability dan AVE telah memenuhi kriteria. Model struktural merupakan model yang menjelaskan hubungan antar variabel, signifikansi hubungan antar variabel dapat dilihat pada nilai $t$-statistic yang didapatkan setelah dilakukan bootsraping. Variabel satu memiliki pengaruh yang signifikan terhadap variabel lainnya apabila nilai $t$-statistic lebih besar dari 1,645. Pengaruh antar variabel dapat dilihat dari $p$ value yang nilainya kurang dari 0,05 .

Tabel 5. Koefisien dan signifikansi model struktural

\begin{tabular}{lllllc}
\hline Hipotesis & Koefisien & $\mathbf{t}$ statistic & $\mathbf{t}$ tabel & P value & Kesimpulan \\
\hline KT terhadap KK & 0,651 & 13,567 & 1,645 & 0,000 & terbukti \\
\hline KK terhadap KO & 0,602 & 8,392 & 1,645 & 0,000 & terbukti \\
\hline $\begin{array}{l}\text { KT terhadap KO } \\
\text { melalui KK }\end{array}$ & 0,238 & 3,291 & 1,645 & 0,002 & terbukti \\
\hline
\end{tabular}

Tabel 5 memberikan informasi nilai koefisien pada model struktural dan signifikansi setiap hubungan variabel. Pada hipotesis KT terhadap KK didapatkan nilai $t$ statistic sebesar 
13,567. Nilai ini lebih besar dari 1,645 sehingga hipotesis pengaruh KT terhadap KK terbukti. Koefisien antara kedua variabel ini sebesar 0,651. Nilai ini memiliki makna bahwa peningkatan pada variabel KT sebesar satu satuan, akan diikuti peningkatan pada variabel PU sebesar 0,651 kali.

Berdasarkan informasi tabel 5 di atas, hipotesis KK terhadap KO terbukti yang artinya variabel KK berpengaruh signifikan terhadap KO. Kesimpulan ini didasarkan pada nilai t statistic nya lebih besar dari 1,645. Koefisien antara kedua variabel tersebut sebesar 0,602. Makna dari nilai koefisien tersebut adalah peningkatan pada variabel KK akan diikuti peningkatan pada variabel KO. Nilai $t$ statistic untuk hipotesis KT terhadap KO melalui KK sebesar 3,291 sehingga dapat disimpulkan KT berpengaruh signifikan terhadap KK. Koefisien yang dihasilkan untuk kedua variabel tersebut sebesar 0,238. Dengan nilai ini, maka peningkatan KT akan berpengaruh terhadap peningkatan $\mathrm{KO}$.

Tabel 6. Nilai R square

\begin{tabular}{rr}
\hline Variabel & R square \\
\hline KT & 0,57 \\
KK & 0,63 \\
KO & 0,46 \\
\hline
\end{tabular}

Evaluasi terhadap model struktural pada PLS dapat diketahui dari nilai goodness of fit atau R2.. Nilai ini memberikan gambaran bahwa model dapat menjelaskan variasi atau keragaman data Kepemimpinan Transformasional sebesar 57\%. Koefisien untuk varibel Kepuasan Kerja sebesar 63\%, dan Komitmen Organisasional sebesar 46\%. Hasil analisis menggunakan metode PLS memberikan kesimpulan bahwa semua hipotesis dalam penelitian ini terbukti

\section{KESIMPULAN}

Model konseptual hubungan gaya kepemimpinan transformasional, kepuasan kerja dan komitmen organisasional didapat kesimpulan setelah menggunakan analisis metode PLS diketahui bahwa variabel Kepemimpinan Transformasional (KT) berpengaruh signifikan terhadap Kepuasan Kerja (KK), Kepuasan Kerja (KK) memiliki pengaruh yang signifikan terhadap terhadap Komitmen Organisasional (KO), dan Kepemimpinan Transformasional (KT) memiliki pengaruh signifikan terhadap Komitmen Organisasional (KO) melalui 
Kepuasan Kerja (KK) sebagai variabel intervening pada pegawai Fakultas X Perguruan Tinggi $Y$.

\section{UCAPAN TERIMA KASIH}

Alhamdulillah, puji syukur atas kehadirat Allah SWT dengan segala rahmat, ridho, petunjuk dan hidayah-Nya. Shalawat serta salam dihaturkan kepada Nabi Besar Muhammad SAW atas tuntunannya, serta para sahabat dan semua pihak yang senantiasa istiqomah berjuang dalam iman dan Islam. Ucapan terima kasih ditujukan kepada Dr. Dwi Ratmawati, M.Com selaku dosen pembimbing orang tua, kakak, keluarga, kekasih, teman-teman serta semua pihak yang telah mendukung pembuatan penelitian ini

\section{DAFTAR PUSTAKA}

Ahmed, Imtiaz, et al. 2013. "Employee Performance Evaluation: a Fuzzy Approach". International Journal of Productivity and Performance Management. Vol. 62. No. 7. Pp. 718-754.

Aranya, N., R. Lachman and J. Amernic. 1982. "Accountants'Job Satisfaction: A Path Analysis". Accounting, Organizations and Society. Vol. 7. No. 3. pp. 201-215.

Arikunto, Suharsimi. 2002. Manajemen Penelitian. Jakarta: Rineka Cipta.

Armstrong, Michael. 1999. The Art of HRD: Human Resource Management (Vol 2) London: Crest Publishing House.

Badeni. (2013). Kepemimpinan dan Perilaku Organisasi. Bandung: Alfabeta.

Bass, B. M., \& Avolio, B. J. (1995). MLQ, Multifactor leadership questionnaire. Redwood City, CA; Mind Garden.

Bass, B. M. \& Avolio, B. J. (2000). MLQ Multifactor Leadership Questionnaire. Redwood City: Mind Garden.

Bavendam, J. 2000. "Managing Job Satisfaction". Special Report, Vol 6, Bavendam Research Incorporated, Mercer Island.http://www.bavendam.com/

Bernardin, H. John and Joyce, E.A. Russel., 1993. Human resource Management An Experiental Approach. Series In Management. New York: McGraw-Hill.

Burns, J. M.(1978). Leadership. New York: Harper \& Row.

Byars, L.L and L.W. Rue., 2000. Human Resource and Personal Management. United State of America : Richard D. Irwin. Inc.

Cummings, G. G., Macgeregor, T., Davey, M., Lee, H., Wong, C. A., Lo, E., Muise, M., \& Stafford, E. (2010). Leadership styles and outcome patterns for the nursing workforce and work environment: A systematic review. International Journal of Nursing Studies, 47, 363-385.

Daft, Richard, L. (2011). The Leadership Experience (5th ed). South Western Publication.

Davis, K dan Newstrom. (1995). Perilaku dalam Organisasi. Jakarta: Erlangga.

Davis, Keith (1985). Perilaku Dalam Organisasi, Jilid I, Edisi 7. Jakarta : Penerbit Erlangga.

Davis, Keith and Newstrom, John W. 1993. Organizational Behavior. United States of America: McGraw-Hill International Book Company.

Dessler, Gary. 1998. Manajemen Sumber Daya Manusia. Edisi Bahasa Indonesia. Terjemahan. Jakarta : PT Prentice Hall Inc.

Evan, J.R, and William M. Lindsay. 2006. The Management and Control of Quality. $5^{\text {th }}$ 
edition. South Western: Thomson Learning.

Ghozali, Imam. 2001. Aplikasi Multivariat. Edisi I. Semarang: Universitas Diponegoro.

Gibson, James L, John M. Ivancevich dan James H. Donnely Jr.. 1996, Organisasi dan Manajemen : Perilaku, Struktur, Proses, Edisi Keempat, Terjemahan, Jakarta: Erlangga.

Gruenberg, B. 1980. The happy worker: Ananalysis of educational and occupational difference in determinants of job satisfaction. American journal of sociology. 86,247271.

Handoko, T. Hani., 2001. Manajemen Personalia dan Sumber Daya Manusia, Yogyakarta : Andi Offset.

Heidjrachman, Ranupandojo dan Husnan, Suad. 2002. Manajemen Personalia. Yogyakarta : BPFE.

Hemphill, J. K., \& Coons, A. E. (1957). Development of the leader behavior description questionare. Colombus: Bereau of Bussiness Research, Ohio State University.

Hersey, P., dan Blanchard, K. 1992. Manajemen Perilaku Organisasi. Jakarta: Erlangga.

Hidayah, Noer. Fernanda, Jerhi Wahyu (2021) Analisis Penerimaan Aplikasi Pembelajaran Online Menggunakan Technology Acceptance Model 3 dan Partial Least Square Structural Equation Model (PLS-SEM). Jurnal Factor M Vol 3 no.2. DOI: 10.30762/factor-m.v3i2.3097

Ilyas Yaslis. (2005). Kinerja, Teori dan Penelitian. Yogyakarta: Liberty.

Jean, L. 2004. 'Effect of Leadership and Leader-Member Exchange on commitment Leadership and Organizational ', Developmental Journal, vol. 26 no 8, pp. 655-72.

Karsono. 2008. Pengaruh Komitmen Organisasi Terhadap Kinerja dengan Motivasi dan Kepuasan Kerja sebagai Variabel Pemediasi. Jurnal Akuntansi Bisnis. Vol.8(2): 151 164.

Kreitner dan Kinichi (1998), Organization Behavior. Irwin. McGraw-Hill, Boston.

Luthans, Fred. 1995. Organizational Behavior. Seventh edition. New Jersey: Prentice Hall,Inc.

Mangkunegara, Anwar Prabu. 2001. Manajemen Sumber Daya Manusia Perusahaan. Bandung: PT Remaja Rosdakarya.

McShane, Steven L. dan Mary Ann Von Glinow, 2000. Organizational Behavior. United States of America: McGraw-Hill Companies.

Miles, S. J., \& Mangold, G. (2002). The impact of team leader performance on team members' satisfaction: the subordinate's perspective. Team Performance Management: An International Journal, 8(5/6), 113-121.

Miller, L.E. 1991. Agr. Edu 885 research methods. Ohio State University.

Moncrief, W. C., Babakus, E., Cravens, D., Johnston, M. 1997. Examination the Antecedent and Concequences of Salespeoples Job Stress. European Journal of Marketing Examining / Salesperson Job Stress, Vol. 31, No. 11/12, pp. 786-798.

Rivai, Veithzal. (2005). Manajemen Sumber Daya Manusia Untuk Perusahaan, Dari Teori Ke Praktek. Jakarta: PT. Rajagrafindo Persada.

Robbins, Stephen P. 2001. Perilaku Organisasi, Edisi Bahasa Indonesia. Jakarta: PT. Prenhallindo.

Roseman, Edward. 1981. Managing turnover: A positive approach. New York: Amacom.

Schepers, J., Wetzels, M., \& Ruyter, K. D. (2005). Leadership styles in technology acceptance: do followers practice what leaders preach? Managing Service Quality, 15(6), 496-508.

Stup, R. E. (2005). Human resource management and dairy employee organizational 
commitment. The Pennsylvania State University, Pennsylvania.

Sugiyono. 2010. Metode Penelitian Administratif. Bandung: Alfabeta.

Van Scooter, J.R. 2000. "Relationship of Task Performance and Contextual Performance With Turnover, Job Satisfaction, and Affective Commitment", Human Resource Management Review, 10 (1) : 79-95.

Yousef, D.A. (2000), "Organizational commitment: a mediator of the relationships of leadership behavior with job satisfaction and performance in a non-Western country", Journal of Managerial Psychology, Vol. 15 No. 1, pp. 6-24.

Yukl, G.A. 1989. Managerial Leadership A Review of Theory and Research, Journal of Management Vol 15 No. 2, PP 251-289.

Yukl, Gary. 2010. Kepemimpinan Dalam Organisasi (Edisi Kelima). Alih bahasa: Budi Supriyanto. Jakarta: PT. Indeks.

Yuwono, dkk. 2005. Psikologi Industri dan Organisasi. Cetakan pertama. Surabaya: Fakultas Psikologi Unair.

\section{(c) (i)}

(C) 2021 by authors. Content on this article is licensed under a Creative Commons Attribution 4.0 International license. (http://creativecommons.org/licenses/by/4.0/). 